\title{
Potentados locais e seu braço armado: as vantagens e dificuldades advindas do armamento de escravos na conquista das Minas*
}

Ana Paula Pereira Costa**

\section{RESUMO}

O presente texto tem por objetivo explorar as vantagens, utilidades e também os reveses advindos do uso de milícias particulares de escravos armados, montadas pelos potentados locais e aproveitadas pela Coroa portuguesa e autoridades metropolitanas na comarca de Vila Rica na primeira metade do século XVIII.

Palavras-chave: escravos armados, potentados locais, construção da autoridade, tensôes, Minas Gerais colonial.

\begin{abstract}
The present essay explores the advantages, functions, and also disadvantages of using of private militias of armed slaves, organized by local potentates and used by the Portuguese Crown and metropolitan authorities in Vila Rica county in the first half of the eighteenth century.
\end{abstract}

Keywords: armed slaves, local potentates, construction of authority, tensions, colonial Minas Gerais.

Artigo recebido em 31 de outubro de 2012 e aceito em 4 de março de 2013.

* Pesquisa financiada pela Faperj e Capes.

** Doutora em história social pela Universidade Federal do Rio de Janeiro, professora recém-doutora da UFRJ-Capes/ Faperj. Rio de Janeiro, RJ, Brasil. E-mail: anappcosta@ig.com.br. 
A historiografia sobre o período colonial consolidou na última década estudos que ressaltam critérios definidores dos grupos que constituíam suas elites. Dentre estes, se destacam a concessão de mercês, o ideário da conquista, o desempenho de cargos administrativos, o exercício do poder concelhio e o estabelecimento de redes sociais. ${ }^{1}$ A maior parte destes estudos buscou entender como as elites coloniais operavam por meio de uma complexa política de alianças, lutando ao mesmo tempo por privilégios e cargos para garantir uma posição de destaque na hierarquia da colônia e negociar interesses próprios em vantagem com a Coroa.

Dito de outro modo, parte desta elite colonial, por intermédio de uma intrincada rede de relaçóes econômicas, político-administrativas, parentais e de reciprocidade — ligando os mais remotos rincôes da colônia entre si a outras partes do Império e ao centro de poder e dos negócios no Reino —, se constituiu pela conquista da terra, pela ascensão de postos administrativos e pela obtençáo de terras e mercês.

Contudo, em relação às elites europeias do Antigo Regime, a especificidade mais marcante desta elite colonial estaria no fato de ter se promovido em uma sociedade escravista, que se gerou por sua vez na dinâmica do tráfico negreiro. ${ }^{2} \mathrm{O}$ tráfico atlântico de escravos africanos se constituía, na verdade, em uma atividade estruturante da forma de ser do império português nos diferentes quadrantes do mundo no século XVIII. ${ }^{3}$

Desta forma, cabe destacar que, na América portuguesa, um dos principais elementos a caracterizar a elite colonial era a posse de escravos. A importância dos escravos para tal grupo nos é revelada por diferentes pontos: pela utilização do escravo como mão de obra em atividades econômicas mantenedoras do cabedal desses indivíduos, crucial para a sustentação material de sua "qualidade" social; pela quantidade de escravos, juntamente com a posse de terras, traduzir-se em signo de riqueza e prestígio social nesta sociedade; por fim, pela atuaçáo como braço armado de seus senhores e por seu importante papel como elo na constituição de redes de reciprocidade que a elite estabelecia com diferentes grupos, as quais eram cruciais para a demarcação de hierarquias e posiçóes sociais.

No contexto da descoberta de Minas Gerais, tempos confusos e conturbados, a prática de se usar escravos armados constituiu-se em algo fundamental para membros da elite local, os potentados, preocupados em construir e manter seu poder e autoridade. Os indivíduos que decidiram se embrenhar por matas fechadas, por trilhas indígenas pouco conhecidas, por regióes não exploradas, tudo em nome do metal dourado, das pedras preciosas e do enriquecimento imediato, sabiam da necessidade de se valer desse recurso para serem bem-sucedidos em suas empreitadas. Tal fato levou à conquista do sertáo, que

\footnotetext{
${ }^{1}$ FRAGOSO, João Luís Ribeiro; BICALHO, Maria Fernanda; GOUVÊA, Maria de Fátima (Org.). O Antigo Regime nos trópicos: a dinâmica imperial portuguesa (séculos XVI-XVIII). Rio de Janeiro: Civilização Brasileira, 2001; FRAGOSO, João Luís Ribeiro. A nobreza vive em bandos: a economia política das melhores famílias da terra do Rio de Janeiro, século XVII: algumas notas de pesquisa. Tempo. Revista do Departamento de História da UFF, Niterói, v. 15, p. 11-35, 2003; BICALHO, Maria Fernanda. A cidade e o Império: o Rio de Janeiro no século XVIII. Rio de Janeiro: Civilização Brasileira, 2003; MELLO, Evaldo Cabral de. Rubro veio. O imaginário da restauraçáo pernambucana. Rio de Janeiro: Topbooks, 1997; CAMPOS, Maria Verônica. Governo de mineiros: “de como meter as Minas numa moenda e beber-lhe o caldo dourado”. Tese (doutorado em história) — Faculdade de Filosofia, Letras e Ciências Humanas, Universidade de São Paulo, São Paulo, 2002; FRAGOSO, João Luís Ribeiro; ALMEIDA, Carla Maria Carvalho de; SAMPAIO, Antonio Carlos Jucá de (Org.). Conquistadores e negociantes: histórias de elites no Antigo Regime nos trópicos. América Lusa, séculos XVI a XVIII. Rio de Janeiro: Civilização Brasileira, 2007; FRAGOSO, João Luís Ribeiro; GOUVÊA, Maria de Fátima (Org.). Na trama das redes. Política e negócios no Império Português, séculos XVI-XVIII. Rio de Janeiro: Civilização Brasileira, 2010. ${ }^{2}$ BICALHO, Maria Fernanda. Elites coloniais: a nobreza da terra e o governo das conquistas. História e historiografia. In: MONTEIRO, Nuno G.; CARDIM, Pedro; CUNHA, Mafalda Soares da (Org.). Optima pars: elites ibero-americanas do Antigo Regime. Lisboa: ISC — Imprensa de Ciências Sociais, 2005. p. 97.

${ }^{3}$ FRAGOSO, João Luís Ribeiro; GOUVÊA, Maria de Fátima (Org.). Na trama das redes, op. cit. p. 13.
} 
mais tarde chamou-se Minas Gerais, a se realizar em meio a um cenário marcado pela violência, conflitos entre interesses opostos e estreita relação entre autoridade e poder. ${ }^{4}$

Porém, se muitos relatos sobre esses primeiros anos de ocupação do território mineiro revelam que era comum, e até mesmo necessário, que alguns indivíduos, constituintes do grupo de poderosos locais, agregassem em torno de si um séquito de escravos armados para sua proteção, para publicizar poder ou para utilizá-los em prol da Coroa portuguesa, visando às mercês régias que garantissem seus status, fica claro também que tal prática apresentava contratempos. Assim, se em várias ocasiōes os escravos armados se compuseram como elementos cruciais para o alcance e a manutenção da autoridade dos potentados e para auxílio ao rei e às autoridades metropolitanas na defesa dos povos, em outras, se apresentavam como obstáculo para a manutenção da tranquilidade pública, ao fugirem, organizarem quilombos, praticarem crimes e violências contra a população local, ou ao serem usados pelos potentados, como parte de uma milícia particular, em desmandos e contendas pessoais.

Especialmente em relação a esse último ponto, as autoridades não ficaram alheias e deixaram documentadas tais ambiguidades. Por exemplo, na "Relação do princípio do descoberto destas Minas Gerais e os sucessos de algumas coisas mais memoráveis que sucederam do seu princípio até o tempo em que as veio governar o Excelentíssimo Senhor dom Brás da Silveira", o fenômeno do armamento dos escravos é descrito como algo que proporcionava respeito e vantagem para certos grupos, mas que também indicava audácia e violências. ${ }^{5}$ Segundo o autor da Relação: "naquele tempo quem tinha de 20 a 30 escravos era respeitado pelos seus companheiros, sobretudo os paulistas que gostavam de exibir suas armas como fastos indicantes de suas dissimuladas proezas". ${ }^{6}$ Tanto que um renomado sertanista paulista que habitava a capitania neste período, Jerônimo Pedroso de Barros, tinha a alcunha de "Jerônimo Poderoso" "por ter este também bastante escravos, saindo sempre com sua gente que se lhe tinha agregado a ele, todos armados".

O governador Martinho de Mendonça Pina e Proença, que em 1730 iria para Minas organizar as arrecadaçóes dos quintos e dos diamantes, em relatório que escreveu ao rei d. João $\mathrm{V}$, resumiu assim os anos iniciais da região em relação aos potentados:

Era naquele tempo o país habitado por paulistas acostumados à insolência e soltura, e de portugueses de baixíssima extração, sem cultura; nem uns nem outros tinham de seu mais que armas, negros e ouro que lhe davam atrevimento e ocasião para as revoltas, receiando pouco o castigo porque era fácil se retirarem ao mato. ${ }^{8}$

Neste sentido, o presente texto tem por objetivo explorar as vantagens, as utilidades e também os reveses advindos do uso de milícias particulares de escravos armados ${ }^{9}$ montadas pelos potentados locais

\footnotetext{
${ }^{4}$ PAIVA, Eduardo França. De corpo fechado: o gênero masculino, milícias e trânsito de culturas entre a África dos mandingas e as Minas Gerais da América, no início do século XVIII. In: LIBBY, Douglas Cole; FURTADO, Júnia Ferreira. Trabalho livre, trabalho escravo. Brasil e Europa, séculos XVIII e XIX. São Paulo: Annablume, 2006. p. 113-114.

${ }^{5}$ Códice Costa Matoso. Coordenação-geral de Luciano Raposo de Almeida Figueiredo e Maria Verônica Campos Belo Horizonte: Fundação João Pinheiro, 1999. vol. I e II. p. 194-202.

${ }^{6}$ Ibid., p. 197.

${ }^{7}$ Ibid.

${ }^{8}$ LIMA JR., Augusto de. Vila Rica do Ouro Preto. Síntese histórica e descritiva. Belo Horizonte: Edição do autor, 1957. p. 73.

${ }^{9}$ Nos referimos a um uso privado dos escravos, uma espécie de guarda pessoal constituída informalmente, isto é, sem a conotação militar que se associa às tropas de negros montadas recorrentemente durante todo o período colonial em caso de necessidade, sendo a mais famosa conhecida como "terço dos Henriques". Por isso, optamos por nomear o séquito de escravos armados que eram usados pelos potentados em suas diligências como milícia particular, justamente para passar essa ideia de informalidade, num sentido genérico que desse a noção de se tratar de algo que, apesar de ser usado em determinados momentos com fins militares, não pode ser atrelado à estrutura formal da organização militar lusitana. Esta se
} 
e aproveitadas pela Coroa e autoridades metropolitanas na comarca de Vila Rica na primeira metade do século XVIII.

Armar escravos não era algo nada excepcional em sociedades escravistas, sendo esta uma prática comum a diferentes épocas e lugares, que remonta inclusive à escravidão antiga. Citando o uso de escravos armados pelos imperadores romanos do primeiro século da era cristá, David Brion Davis destaca que:

Como nesse período a disputa de poder estava no auge e a segurança dessas elites [romanas] se tornou algo complicado, a utilização de escravos armados como "guarda-costas" pessoais — sobretudo os escravos de regiōes distantes separados de suas famílias e clãs — se tornou matéria comum. ${ }^{10}$

O mesmo fenômeno é encontrado na África moderna na região de Moçambique, estudada por Allen Isaacman e Derek Peterson, ${ }^{11}$ bem como por José Capela. ${ }^{12}$ Este autor, analisando a sociedade dominical do Zambeze entre os séculos XVII e XIX, através da sua instituição-chave, o prazo, dedica um capítulo para analisar o grupo dos chicunda. Segundo Capela, os portuguesess que colonizaram a regiáo foram atraídos pelas perspectivas do ouro e, ao longo dos séculos XVI e seguintes, foram se fixando a partir do mar para o interior, senhoreando terras e pessoas, utilizando, para isso, todos os meios disponíveis, desde a negociação até a conquista por meios bélicos. Estavam a implantar um sistema dominial. As terras doadas e senhoreadas eram conhecidas como prazos da Coroa. A doação tinha por objetivo o povoamento da região, ou seja, a ocupação das terras por europeus de origem e de ascendência. Portanto, mais do que ao cultivo, as terras destinavam-se ao acantonamento dos escravos e dos colonos. Deste modo, os senhores dos prazos não tinham como fonte principal de rendimento o cultivo da terra, mas sim o comércio, o garimpo ou a mineraçáo do ouro e os transportes no Zambeze. Os prazos possuíam numerosos escravos que se empregavam em diversas atividades, entre as quais tomava particular importância o comércio pelo interior (os escravos ligados a esta atividade eram chamados de muçambazes) e a caça aos elefantes. Os escravos que se dedicavam a essa última atividade eram denominados chicunda, designação também utilizada para os escravos armados que, em geral, faziam o policiamento do prazo, cobravam os impostos e formavam os exércitos privados destes senhores de

constituía a partir de três tipos específicos de forças: os corpos regulares (conhecidos também por tropa paga ou de linha), as milícias ou corpo de auxiliares e as ordenanças ou corpos irregulares. Mas havia outras formas de organização mais específicas que subdividiam as forças de acordo com as hierarquias sociais. No caso dos negros, poderiam ser agrupados, basicamente, em quatro espécies de milícias: as companhias auxiliares de infantaria; as companhias de ordenanças de pé; os corpos de pedestres e os corpos de homens-do-mato. Essas milícias foram institucionalizadas nas Minas a partir dos primeiros anos do Setecentos e foram vistas de maneiras distintas pelas diversas autoridades portuguesas. A este respeito ver: COTTA, Francis A. No rastro dos Dragóes: universo militar luso-brasileiro e as políticas de ordem nas Minas setecentistas. Tese (doutorado em história) — Universidade Federal de Minas Gerais, Belo Horizonte, 2005. Ver também: COSTA, Ana Paula Pereira. Atuação de poderes locais no Império Lusitano: uma análise do perfil das chefias militares dos corpos de ordenanças e de suas estratégias na construção de sua autoridade. Vila Rica (1735-1777). Dissertação (mestrado em história social) - Programa de Pós-Graduação em História Social, Universidade Federal do Rio de Janeiro, Rio de Janeiro, 2006. ${ }^{10}$ DAVIS, David B. Introduction. In: BROWN, Christopher Leslie; MORGAN, Philip D. (Org.). Arming slaves: from classical times to the modern age. New Have; Londres: Yale University Press, 2006. p. 4 (traduçáo livre).

${ }^{11}$ ISAACMAN, Allen; PETERSON, Derek. Making the Chikunda: military slavery and ethnicity in southern Africa, 1750-1900. In: BROWN, Christopher Leslie; MORGAN, Philip D. (Org.). Arming slaves, op. cit.

${ }^{12}$ CAPELA, José. Donas, senhores e escravos. Porto: Edições Afrontamento, 1995. 
prazos. Eles comporiam, assim, um corpo de elite de escravos utilizado pelos portugueses que se apresentava ao serviço militar sempre que chamado. ${ }^{13}$

Allen Isaacman e Derek Peterson também estudaram os chicunda, entre os anos de 1750 e 1900, destacando que os portugueses se empenharam em criar uma tradicional classe de escravos africanos que viam a si mesmos como ferozes conquistadores. De acordo com os autores, estes escravos eram separados de suas famílias e tribo desde o nascimento e criados por outros grupos como outsiders. Foram utilizados não somente em combates e nas investidas para coletar escravos e mandá-los em navios negreiros para o Brasil, mas também como policiais e inspetores e como experientes caçadores de elefantes que poderiam ajudar na demanda do Novo Mundo por marfim. Mas, a despeito de seu poder e bravura, os chicundas ainda eram escravos que viviam e obedeciam às ordens num mundo altamente regimentado. $^{14}$

No Novo Mundo, o fenômeno também se fazia presente. Para a América Inglesa, Ira Berlim analisa o armamento de escravos e a montagem de milícias negras desde o início de sua colonização. ${ }^{15} \mathrm{Na}$ Flórida, por exemplo, o autor destaca que escravos fugitivos foram incorporados às milícias negras para lutar ao lado dos espanhóis na guerra de Yamasse para defender St. Augustine (cidade no litoral norte da Flórida, fundada pelos espanhóis em 1565) contra um ataque inglês, com promessas de prêmios e recompensas, tais como a liberdade, da Coroa espanhola. ${ }^{16}$ Já na Louisiana, os milicianos negros ajudaram a combater os homens brancos - primeiro lutando ao lado dos franceses durante a rebeliáo Natchez e depois ao lado dos espanhóis, que tinham longa experiência de emprego de soldados negros. Como soldados, em nome dos franceses e depois da Coroa espanhola, os combatentes escravos e negros livres não somente subjugavam os intrusos europeus e os índios hostis, mas também disciplinavam os escravos das plantations e capturavam fugitivos. No processo, tornaram-se uma extensão política, cultural e às vezes física da sociedade branca. Por mais que fossem discriminados, seu serviço na causa do homem branco habilitava-os, inclusive, a subirem a escada social da colônia. ${ }^{17}$

Para a América espanhola, Jane Landers destaca que na Espanha colonial há vários exemplos de uso de escravos armados nas campanhas militares contra as populaçóes indígenas, nas quais se formavam grandes tropas, cujo número muitas vezes ultrapassava cem integrantes. Porém, se tais tropas foram em muitos momentos fundamentais para a Coroa espanhola em seus propósitos colonizadores, Landers não deixa de ressaltar também as preocupaçóes que giravam em torno do risco de se armar tấo grande número de escravos, pois controlar essas numerosas tropas não era tarefa fácil. ${ }^{18}$

Para a América portuguesa, a historiografia brasileira está repleta de exemplos de uso de escravos em milícias públicas e privadas. Analisando o auxílio prestado pelas elites pernambucanas na guerra para restauração pernambucana contra os holandeses, Evaldo Cabral de Mello ressalta que, neste conflito, tal atuação era feita com suas vidas, cabedais e escravos armados. ${ }^{19}$

\footnotetext{
${ }^{13}$ CAPELA, José. Como as Aringas de Moçambique se transformaram em Quilombos. Tempo. Revista do Departamento de História da UFF, Niterói, v. 20, p. 72-97, 2005, p. 73-75. Ver também: CAPELA, José. Donas, senhores e escravos, op. cit. p. 196-209.

${ }^{14}$ Ver: ISAACMAN, Allen; PETERSON, Derek. Making the Chikunda, op. cit. p. 95-119.

${ }^{15}$ Para maiores informações sobre a difusão de armas entre a população e existência de milícias negras na América do Norte, ver: CRAMER, Clayton E. Armed America: the remarkable story of how and why guns became as american as apple pie. Nashville, Tennessee: Nelson Current, 2006.

${ }^{16}$ BERLIN, Ira. Geraçôes de cativeiro. Uma história da escravidão nos Estados Unidos. Rio de Janeiro: Record, 2006. p. 59-60.

${ }^{17}$ Ibid., p. 116.

${ }^{18}$ LANDERS, Jane. Transforming bondsmen into vassals: arming slaves in colonial Spanish America. In: BROWN, Christopher Leslie; MORGAN, Philip D. (Orgs.). Arming slaves, op. cit. p. 121.

${ }^{19}$ MELLO, Evaldo Cabral de. Rubro veio, op. cit. cap. 3.
} 
João Fragoso, em vários dos seus trabalhos em que analisa as melhores famílias da terra no Rio de Janeiro seiscentista, destaca que nos serviços prestados por elas à Coroa portuguesa na conquista deste território, visando às mercês régias, não raro utilizavam escravos e índios flecheiros como braço armado. ${ }^{20}$

Estudando a capitania de Minas Gerais no século XVIII, Hendrik Kraay observou que o fato de os senhores armarem seus próprios escravos tornou-se rotina nas fronteiras e durante o período do boom da mineração. Isso acontecia, segundo o autor, tanto para a proteção dos senhores, quanto em momentos em que os mesmos cometiam desmandos e violências, praticando crimes com a ajuda desses escravos armados, sendo tais açôes uma extensão dos serviços que os escravos deviam prestar a seus donos. ${ }^{21}$

Seguindo essa lógica, destacaremos daqui em diante alguns relatos deixados por potentados da região enfocada, nos quais colocam o ato de armar escravos como mecanismo comum e essencial para demonstração de poder; para o sucesso de empreitadas em que auxiliavam a Coroa portuguesa e autoridades metropolitanas, notadamente governadores, na manutenção da ordem pública e para o alcance de mercês régias que afirmariam seu status. Entretanto, igualmente, ressaltaremos os contratempos que esses mesmos relatos deixam explícitos acerca desse fenômeno. Dito de outro modo, apesar de o armamento de escravos ser uma prática que se repetiu com frequência, ela não deixou de fomentar violências e desmandos não só da parte dos proprietários, que haviam montado suas milícias escravas, mas também por parte dos demais habitantes da regiáo, entre eles negros - escravos ou não - que se valiam dessa situação relativamente comum para defender interesses, cometer crimes e incitar revoltas.

O relato deixado pelo sargento-mor Paulo Rodrigues Duráo exemplifica bem o que estamos querendo dizer. Este potentado, saído da região de Évora, Coutos de Alcobaça, migrou para a América portuguesa e sertanejou nas Minas Gerais em seus primórdios, sendo um dos seus descobridores e primeiros povoadores. Estabeleceu-se inicialmente no Morro Vermelho do Sabará, mudando-se depois para o Inficcionado onde ganhou patente de capitão de auxiliares, posto que exerceu entre janeiro de 1718 a dezembro de $1719 .{ }^{22}$ Conseguiu construir nas Minas, além de grande prestígio e status evidenciado pela sua posiçáo de conquistador e primeiro povoador do Inficcionado, ${ }^{23}$ pelas várias patentes possuídas, ${ }^{24}$ pela ocupação dos cargos de guarda-mor, juiz e vereador na Câmara da Vila do Carmo ${ }^{25}$ —, uma destacada posição econômica. Dedicando-se às atividades da mineração, agricultura, bem como à ocupação de senhor de engenho, enriqueceu ao longo de sua vida formando um patrimônio composto por várias propriedades com engenho, lavras, senzalas, terras de cultura, criaçôes de porcos e gado vacum, objetos como joias, roupas finas, prataria, armas de fogo, tudo avaliado em 53:196\$265, ${ }^{26}$ uma quantia considerável que fazia do sargento-mor Paulo Rodrigues Durão um dos homens mais abastados da região.

Tal posição era ainda mais reforçada pela quantidade de escravos que possuía. Desde que se estabeleceu nas Minas, foi formando um plantel cada vez mais numeroso para se dedicar às atividades econômicas das quais se ocupava. Isso pode ser constatado se acompanharmos o movimento de formação de seu plantel nas listas para cobrança dos quintos reais (imposto de $20 \%$ sobre a produçáo aurífera) a

\footnotetext{
${ }^{20}$ FRAGOSO, João Luís Ribeiro. A nobreza vive em bandos, op. cit. p. 9.

${ }^{21}$ KRAAY, Hendrik. Arming slaves in Brazil from the seventeenth century to the nineteenth century. In: BROWN, Christopher Leslie; MORGAN, Philip D. (Org.). Arming slaves, op. cit. p. 147.

${ }^{22}$ FRANCO, Francisco de Assis Carvalho. Dicionário de bandeirantes e sertanistas do Brasil. Belo Horizonte: Itatiaia; São Paulo: Ed. USP, 1989. p. 145; Arquivo Nacional da Torre do Tombo. Registro geral de mercês. Paulo Rodrigues Durão. Patente. João V, livro 12, folha 302, microfilme 161.

${ }^{23}$ FRANCO, Francisco de Assis Carvalho. Dicionário de bandeirantes e sertanistas do Brasil, op. cit. p. 145.

${ }^{24}$ Arquivo Histórico Ultramarino/MG/cx.:4; doc.:76.

${ }^{25}$ Acórdãos da Câmara Municipal de Mariana. Arquivo Público Mineiro. Seção Colonial — Cód. 02, 05 e 06.

${ }^{26}$ Casa Setecentista de Mariana, 1o ofício - Inventário post-mortem de Paulo Rodrigues Durão. Códice 115, auto 2377 (1743).
} 
que tivemos acesso, nas quais aparece o nome deste potentado e de seus escravos, até chegarmos a seu inventário. ${ }^{27}$ A primeira lista em que encontramos o nome de Paulo Rodrigues Durão é uma referente aos anos de 1718-1720 para a freguesia do Inficcionado, na qual surge como senhor de 76 escravos. ${ }^{28}$ Em outra lista feita para o ano de 1725 para a região da Vila do Carmo e seu termo, consta que Paulo Rodrigues Durão é senhor de 60 escravos, ${ }^{29}$ e no final de sua vida temos contabilizado em seu inventário, datado de 1743 , um plantel de 129 cativos. $^{30}$

Percebe-se que, ao longo de sua vida, este potentado procurou investir na compra desse bem precioso, ocorrendo pequenas variaçôes na conformação de seu plantel durante os anos visualizados nas listas de quinto e em seu inventário. Sem dúvida alguma, além de mão de obra e força econômica para desempenho das atividades a que se dedicava, tais escravos foram também de grande utilidade e redirecionados dessas atividades econômicas para desempenhar funçôes bélicas em momentos de necessidade. Não por acaso, em 1720, ano em que, segundo a lista de quinto do Inficcionado, Paulo Rodrigues Durão era senhor de 76 cativos, ele pôde retirar alguns deles de suas atividades de mineração/agricultura para:

\begin{abstract}
Haver-se com muito zelo na sublevaçáo que os mesmos desta vila rica fomentados de pessoas malignas fizeram contra o governador por este não os deixar viver na continuação dos roubos e insultos, procedendo o dito com toda a fidelidade porque logo que o Conde de Assumar lhe fez aviso saiu em socorro trazendo todos os seus escravos armados que sáo numerosos e muitas pessoas brancas sustentando todos a sua custa no que fez considerável despesa de sua fazenda. ${ }^{31}$
\end{abstract}

Atuou também na cobrança dos quintos do distrito do Inficcionado:

(...) E sendo encarregado da cobrança do quinto do distrito do Inficcionado nos anos de 1717, 1721 e 1722 a fez com grande atividade sem queixa dos moradores do dito distrito fazendo a $\mathrm{V}$. Mag um serviço muito particular achando-se sempre pronto para se entregar nele com a sua pessoa e com a de seus escravos sem atender a despesa alguma pois nas ocasióes em que passam por mato dentro oficiais e soldados os sustenta. ${ }^{32}$

\footnotetext{
${ }^{27}$ Não desconsideramos o fato de que o registro de quintos, por ser uma fonte produzida com finalidades fiscais, apresenta problemas comuns a todas deste tipo. O principal deles é a sonegaçáo de informaçóes, com a finalidade de fugir da tributação, o que geraria um sub-registro da população escrava que se pretende estudar. Entretanto, alguns autores argumentam que, se não há dúvidas quanto ao fato de que o ouro em pó e os diamantes tenham sido objeto de sonegação e de contrabando, é preciso repensar a noção de que os proprietários facilmente ocultassem a existência de escravos. Portanto, embora possa se dizer que certamente a sonegaçáo estivesse presente, ela pode ter sido minimizada pela proximidade do coletor das informaçóes com a população, visto que desde 1710 as câmaras eram incumbidas de preparar listas de proprietários e suas posses de escravos, listas estas que eram utilizadas para calcular o quinto a ser pago pela população local. Assim, os coletores desse imposto eram indivíduos escolhidos pelas próprias câmaras, que moravam na vila e conheciam os moradores. Além disso, este tipo de tributo gerava uma "solidariedade" entre a população, pois era necessário completar certa quantidade de arrobas de ouro, pactuada entre as câmaras da região mineradora. O imposto sonegado por um minerador teria de ser pago por outro. Cf.: LIBBY, Douglas Cole. As populaçôes escravas das Minas Setecentistas: um balanço preliminar. In: RESENDE, Maria Efigênia Lage de; VILLALTA, Luiz Carlos (Org.). História de Minas Gerais. Belo Horizonte: Autêntica, 2007. v. 1, p. 408-409. Ver também: BOTELHO, Tarcísio. Família e escravidão em uma perspectiva demográfica: Minas Gerais (Brasil), século XVIII. In: LIBBY, Douglas Cole; FURTADO, Júnia F. Trabalho livre, trabalho escravo, op. cit. p. 202.

${ }^{28}$ Lista de registro para cobrança dos quintos reais do Inficcionado, 1718-1720. Arquivo Público Mineiro, Coleção Casa dos Contos, códice 1035.

${ }^{29}$ Lista de registro para cobrança dos quintos reais de Mariana e seu Termo, 1725. Arquivo da Câmara de Mariana, códice 150.

${ }^{30}$ Casa Setecentista de Mariana, 1o ofício - Inventário post-mortem de Paulo Rodrigues Durão. Códice 115, auto 2377 (1743).

${ }^{31}$ Revista do Arquivo Público Mineiro, ano 4, fascículo 4, ano 1899. Cartas patentes, código 1229. Patente de Paulo Rodrigues Durão, sargento-mor do Mato Dentro. 27 de outubro de 1722, p. 101-102. Grifos meus.

32 Ibid. Grifos meus.
} 
E ajudou na manutenção da ordem pública em Catas Altas contendo com sua milícia particular insubordinaçôes de negros que andavam armados na regiáo. Segundo o relato:

Como no socorro que deu com seus escravos armados ao tenente general Manoel da Costa Fragoso para se prenderem e castigarem alguns negros revoltosos de régulos insolentes de Catas Altas em Mato Dentro que andavam armados cometendo várias desordens sem atenção aos bandos do Conde de Assumar que havia proibido aos negros o uso de armas para praticar insultos que até sua chegada a estas Minas sucediam. ${ }^{33}$

Os relatos assinalados nos mostram quando, como e para quem os escravos armados se constituíam elemento vantajoso. Ao mesmo tempo, nos mostram situaçóes em que isso náo ocorria, nas quais acabavam por se constituírem em ameaça para colonos e autoridades.

Para a Coroa e governadores, armar escravos podia ser mecanismo de auxílio na manutenção da ordem ao recorrerem às milícias particulares dos potentados para a realização de serviços de grande dificuldade, tais como a cobrança do quinto, o que nos esclarece Paulo Rodrigues Durão ao assinalar o uso de seus escravos armados para cobrar por três vezes o quinto do distrito do Inficcionado. Ou para ajudar na contenção de revoltas locais, como fez o referido potentado na sedição de Vila Rica em 1720, ao lado do governador conde de Assumar, "trazendo todos seus escravos armados que são numerosos" para atuar como reforço bélico. A mobilização de tais escravos armados prontamente requisitados ou oferecidos por seus senhores para as autoridades metropolitanas como auxílio na contenção de motins, desordens e para regular a vida local assinala, portanto, a necessidade de complementação e assessoramento que as forças militares pertencentes à estrutura formal da organização militar lusitana possuíam ${ }^{34}$ e que eram feitas em conjunto com essas forças informais.

Para os potentados, os escravos armados eram importantes mecanismos de demonstração pública de poder e elemento fundamental para a prestação de serviços ao rei, visando à aquisição de mercês régias que referendariam e manteriam seu status de elite. Como mencionado, Paulo Rodrigues Durão havia servido no posto de capitão de auxiliares no Inficcionado de janeiro de 1718 até dezembro de $1719 .{ }^{35}$ Em janeiro de 1721, depois de ter ajudado na contenção da Revolta de Vila Rica em 1720 "com toda a fidelidade porque logo que o Conde de Assumar lhe fez aviso saiu em socorro trazendo todos os seus escravos armados que sáo numerosos", ${ }^{36}$ foi recompensado pelo governador $\mathrm{d}$. Lourenço de Almeida com patente de capitão de ordenança do Inficcionado. Atuando como capitão de ordenanças no Inficcionado, continuou prestando serviços de grande ajuda para o dito governador, tais como a cobrança do quinto na referida localidade em 1721 e 1722, na qual "agiu com muito zello fazendo a V. Mag um serviço muito particular achando-se sempre pronto para se entregar nele com a sua pessoa e com a de seus escravos". ${ }^{37}$ Por tais serviços conseguiu novamente ser recompensado com uma patente que lhe conferia prerrogativas de mando e, consequentemente, contribuía para reforçar seu estatuto de nobreza. Deste modo, em 27 de outubro de 1722 recebeu do governador d. Lourenço de Almeida patente de sargento-mor das ordenanças do distrito de Mato Dentro. ${ }^{38}$

\footnotetext{
${ }^{33}$ Ibid. Grifos meus.

${ }^{34}$ Esta era composta pela tropa paga, pelos corpos de auxiliares e pelos corpos de ordenanças. Ver nota 9.

${ }^{35}$ Arquivo Nacional da Torre do Tombo. Registro Geral de mercês. Paulo Rodrigues Durão. Patente. João V, livro 12, folha 302, microfilme 161.

${ }^{36}$ Revista do Arquivo Público Mineiro, ano 4, fascículo 4, ano 1899. Cartas patentes, código 1229. Patente de Paulo Rodrigues Durão, sargento-mor do Mato Dentro. 27 de outubro de 1722, p. 101-102. Grifo meu.

${ }^{37}$ Ibid. Grifo meu.

${ }^{38}$ Ibid. Ver também: Arquivo Histórico Ultramarino/MG/cx.: 4; doc.:76.
} 
A documentação evidencia que os potentados lançavam mão de seus escravos armados na realização de valorosos serviços em prol dos governadores, da Coroa e do bem comum e que isso era um recurso fundamental para o sucesso das diligências. Serviços esses que eram prestados visando honras e mercês régias que engrandeceriam e reforçariam a "qualidade" social afinal buscavam obter e manter posição de mando dentro da sociedade. Em outras palavras, sem os escravos armados ficaria muito difícil para os potentados auxiliar os governadores, a Coroa e o bem comum em momentos de perigo e necessidade. Por isso tais milícias privadas de cativos eram um recurso tão poderoso e constantemente utilizado nessas ocasióes e, por conseguinte, táo mencionado em relatos nos quais os potentados buscavam enaltecer a grandeza e o sucesso de suas açóes para garantir o máximo possível o agraciamento com distinçóes de todo tipo.

Tais milícias eram, assim, forma de publicizarem e medirem o poder que possuíam, pois ter condiçóes de armar quantidades significativas de escravos e "doá-los" para o real serviço era para poucos, para os realmente poderosos. E o fato de os governadores recorrerem a estes potentados (leia-se, a seus recursos financeiros e escravos armados) para auxiliarem na governabilidade local demonstra que o mando e a autoridade desses homens eram socialmente reconhecidos.

Para complementar esse último argumento, pode-se ressaltar também a importância dos escravos como braço armado para os potentados nos momentos em que atuavam como guarda pessoal. Esta era uma sociedade extremamente violenta, principalmente nos anos iniciais de sua formação, com altas taxas de criminalidade, ocorrência de vários levantes ${ }^{39}$ e distúrbios em que eram marcantes disputas intraelites e com estratos inferiores, disputas essas também essenciais para a manutenção e demarcação das posiçóes sociais. Isso nos é evidenciado, por exemplo, quando Paulo Rodrigues Durão argumenta que levou seus escravos armados ao distrito de Catas Altas para combater, ao lado de um tenente-general, "negros revoltosos de régulos insolentes que andavam armados cometendo várias desordens", não obstante a proibição do conde de Assumar para que negros não usassem armas, denotando aqui inconvenientes e ambiguidades que podiam surgir do armamento dos escravos. Nesse caso, homens poderosos da região, tidos como régulos, recorrendo ao uso de milícias privadas para realizar desmandos, defender interesses e afrontar a autoridade do governo armando seus cativos, apesar de proibição declarada.

Além disso, outros perigos resultantes do armamento dos escravos e que, de igual modo, contribuíam para criar um universo de tensão e conflito na localidade, eram as fugas, a formação de quilombos, as rebelióes, a aquisição de experiência militar, o conhecimento de armas. ${ }^{40}$ Os relatos deixados pelo sargento-mor Antonio Martins Leça são um bom exemplo de como pairava na regiáo das Minas uma atmosfera de instabilidade dada pela formação de quilombos, por rebeliôes e pelos crimes e ameaças cometidos não só pelos escravos armados, mas pela população negra mais ampla. Em um processo para se habilitar à Ordem de Cristo, descreve que:

No ano de 1725 ser mandado ao lugar do morro a extinguir um ajuntamento de negros que roubavam aos que passavam por aquele sítio, o que executou prontamente levando em sua companhia 30 negros armados à sua custa.

No ano de 1716 ser encarregado da prisão do capitão Constantino de Paiva (sic) Pereira como também deu outra prisão de um soldado que da praça do Rio de Janeiro se tinha ausentado, lhe foi preciso correr todas as Minas em busca dele acompanhado de seus escravos, em que fez considerável despesa de sua fazenda.

\footnotetext{
${ }^{39}$ No período compreendido entre 1694 e 1736, a capitania de Minas do Ouro vivenciou 46 levantes, sendo que 37 ocorreram entre 1694 e 1720. CAMPOS, Maria Verônica. Governo de mineiros, op. cit. p. 390-398.

${ }^{40}$ LANDERS, Jane. Transforming bondsmen into vassals: arming slaves in colonial Spanish America. In: BROWN, Christopher Leslie; MORGAN, Philip D. (Org.). Arming slaves, op. cit. p. 133.
} 
No ano de 1717 foi mandado a extinguir um ajuntamento de negros na entrada de Vila Rica que estavam roubando e matando e fazendo outros insultos, o que executou levando consigo quarenta negros armados e alguns homens brancos à sua custa, de que resultou com a prisão que fez de vinte negros que trouxe presos fiar o caminho e entrada da vila e desempedida.

E feita esta diligência, tornou com os outros quarenta escravos seus à sua custa a extinguir outro ajuntamento de negros que continuamente estavam fazendo os mesmos insultos, dos quais trouxe quinze presos que foram castigados, o que fez com muito trabalho e risco de vida e despesa de sua fazenda. No ano de 1719 conduziu das minas para o Rio de Janeiro o preso Antonio de Oliveira Leitão, o qual entregou ao governador daquela praça gastando nesta diligência 47 dias e pretendendo os negros daquelas minas levantar-se no dia de quinta-feira de endoenças contra os brancos, foi nomeado para a paragem do morro aonde assistiu com grande valor e zelo do real serviço, havendo-se com igual préstimo no ano de 1720 .

Sendo-lhe ordenado assistisse e fizesse dar cabo da roça dos matos do morro do ouro preto que só serviam para ocultar negros fugidos aquietando com grande prudência as dúvidas que ouve entre os moradores do caminho das minas para o Rio de Janeiro, no ano de 1721, sendo sargento-mor das ordenanças de Vila Rica, em cujo posto foi confirmado por ordem do Conde de Assumar a sossegar o povo da vila de Pitangui, o que fez à sua custa sem despesa alguma da fazenda real, com dez escravos seus armados em cuja diligência gastou 66 dias e da mesma sorte se haver em todas as diligências de que foi encarregado assistindo a todas as juntas que se fez sobre os quintos do ouro em que seu voto era sempre que mais convinha à fazenda real.

Votou com zelo para a cobrança das trinta arrobas dos quintos que conduzia com os seus escravos armados e entregava ao tesouro sem levar ajuda de custo e por vezes mandava os seus escravos trabalhar nos quartéis sem reparo algum do prejuízo que se lhe seguia de morrerem e do ouro que podiam tirar, como requerem os mesmos governadores e oficiais da câmara nas certidóes que apresentava a Eugenio Freire de Andrada, superintendente-geral da casa da moeda. ${ }^{41}$

As situaçóes assinaladas expóem os riscos e a violência que poderiam advir da possibilidade de negros e escravos terem acesso a armas, tais como propiciar fugas, formação de quilombos, levantes, roubos e assassinatos. Circunstâncias essas enfrentadas pelo referido potentado e a população mineira, segundo seu relato, por sucessivos anos. A própria existência de uma legislaçáo que defendia o uso moderado das armas e em alguns casos até mesmo proibia que se armassem escravos na capitania indica que, apesar de trivial, isso era algo que preocupava as autoridades coloniais.

Porém, apesar dos riscos e preocupaçóes, a necessidade posta pelo contexto denota que os senhores precisavam munir seus negros de facas, facóes, paus e até mesmo armas de fogo para que realizassem diversos tipos de trabalhos. Já destacamos, por exemplo, os imprescindíveis reforço e socorro que propiciavam às forças pertencentes à estrutura militar mais formal para atuação em serviços de defesa e ordenamento social e o auxílio que prestavam às autoridades metropolitanas para a realizaçáo de serviços cruciais para o exercício da governabilidade régia em território ultramarino. Além disso, cabe assinalar a proteção que forneciam às elites em um cenário hostil e belicoso de demarcação de territórios de mando. Como indicado anteriormente e na documentação, nas diligências que os potentados realizavam para auxiliar o monarca, os cativos acabavam também por fornecer proteção para seus senhores em estradas e caminhos inóspitos nos quais estavam sujeitos a roubos. Serviam ainda para auxiliar no combate às revoltas locais, para cobrar o quinto, para capturar e punir negros insurgentes. Ou seja, em várias situaçóes, os senhores permitiam aos seus escravos usar armas, pois isso se fazia necessário numa

${ }^{41}$ Arquivo Nacional da Torre do Tombo. Habilitação da Ordem de Cristo de Antonio Martins Leça. Letra A, Maço 51, doc 15. Data: 11 de maio de 1726. Grifos meus. 
conjuntura em que a possibilidade de mobilizar homens para lutar era fator crucial para a sobrevivência, para a definição do poder desses homens, para negociação de privilégios com a Coroa, para o sucesso das diligências de manutenção da ordem e, consequentemente, para a sustentação dos interesses régios. Os potentados enfrentavam assim perigos diversos, tais como quilombolas, criminosos e sublevaçôes a pedido do rei e o faziam à custa de suas vidas, de fazendas e escravos armados.

Para Antonio Martins Leça, natural do Porto, os serviços que prestou ao longo de sua vida a favor de sua majestade certamente o auxiliaram a alcançar uma posição de "qualidade" social destacada e, neste sentido, de prestígio e poder. Como capitão de auxiliares, posto em que foi provido provavelmente em 1714, assistiu na prisão de criminosos em 1716, na contenção de levantes de negros e na realização de rondas para proteger a entrada de Vila Rica em 1717. Ajudou ainda na condução de um preso e no ataque a um quilombo em 1719 e 1720, respectivamente, sempre à custa de seus escravos armados e "grande despesa de sua fazenda". ${ }^{42}$ Por tão valorosos serviços ganhou em 1720 patente de sargento-mor das ordenanças de Vila Rica por ordem do conde de Assumar, ${ }^{43}$ que reconhecia assim não só a importância do auxílio que prestou em momentos de necessidade, mas também a utilidade e o poder que as milícias escravas conferiam para os potentados e, em última instância, para a defesa dos interesses régios. Não por acaso, nos relatos em que homens como Antonio Martins Leça procuram denotar o valor de seus serviços, vem reforçado que estes foram realizados arriscando suas vidas, utilizando suas despesas e escravos armados. Era uma forma de demonstrar não só o dispêndio feito com recursos financeiros e humanos, mas também o poder, a riqueza e o prestígio que possuíam e que os fariam dignos de serem recompensados. Isso evidencia que esses indivíduos iam trilhando seus percursos nas Minas de forma a conquistar uma reputaçáo que poderia lhes render o reconhecimento local e, quem sabe, régio de suas virtudes. Os serviços prestados à monarquia e ao bem comum sempre doando suas vidas, despesas e escravos armados contribuíram para que deles se formassem uma imagem enaltecedora, digna de servir de exemplo aos demais súditos. ${ }^{44}$

Como sargento-mor das ordenanças, Antonio Martins Leça foi em 1721 "sossegar o povo da vila de Pitangui, o que fez à sua custa sem despesa alguma da fazenda real, com dez escravos seus armados". 45 Era de fato homem abastado. Sua riqueza era proveniente da mineração,${ }^{46}$ sendo também revertida para a compra de numeroso plantel de escravos, os quais, como visto anteriormente, foram utilizados variadas vezes como milícia particular para auxiliá-lo em suas jornadas.

Prestigiado pelos feitos e serviços, pela riqueza e poder que procurava demonstrar possuir, em seus relatos Antonio Martins Leça buscava conquistar honrarias que elevariam sua importância, podendo, assim, ser provido em cargos ainda mais cobiçados nos quais seus méritos ganhavam maior destaque. ${ }^{47}$ Deste modo, em 1722 foi eleito juiz ordinário na Câmara de Vila Rica, "procedendo nesta ocupação com muita limpeza de mãos e bom procedimento", cargo que engrandecia ainda mais seu poder na

\footnotetext{
${ }^{42}$ Arquivo Nacional da Torre do Tombo. Chancelaria Régia, João V, Antonio Martins Leça, padrão de tença. Livro 127, p. 237v. Data: 20 de setembro de 1725. Ver também: Arquivo Nacional da Torre do Tombo. Habilitaçáo da Ordem de Cristo de Antonio Martins Leça. Letra A, Maço 51, doc 15. Data: 11 de maio de 1726.

${ }^{43}$ Arquivo Nacional da Torre do Tombo. Chancelaria Régia, João V, Antonio Martins Leça, padrão de tença. Livro 127, p. $237 \mathrm{v}$. Data: 20 de setembro de 1725 .

${ }^{44}$ STUMPF, Roberta. Nobrezas na América portuguesa: notas sobre as estratégias de enobrecimento na capitania de Minas Gerais. Almanack Braziliense, São Paulo, n. 12, p. 119-136, nov. 2010, p. 131.

${ }^{45}$ Arquivo Nacional da Torre do Tombo. Habilitação da Ordem de Cristo de Antonio Martins Leça. Letra A, Maço 51, doc 15. Data: 11 de maio de 1726.

${ }^{46}$ Em sua habilitação para o Santo Ofício dizia ter voltado para sua pátria com mais de 100 mil cruzados. Arquivo Nacional da Torre do Tombo. Familiatura do Santo Ofício de Antonio Martins Leça. Completa, maço 68, doc. 1362. Maio de 1726.

${ }^{47}$ STUMPF, Roberta. Nobrezas na América portuguesa, op. cit. p. 123.
} 
medida em que adentrava os círculos sociais restritos aos "principais da região" ${ }^{48}$ Posteriormente, ocupou ainda os cargos de provedor e juiz almotacé na Câmara de Vila Rica ${ }^{49}$ Cabe sublinhar que os serviços obrados em postos camarários poderiam render além de uma remuneração régia, o reconhecimento local como homem que portava notoriedade e estima social já que, em teoria, só eram providos aqueles que possuíam qualidades que os destacavam da massa de homens comuns. ${ }^{50}$

Buscando reafirmar ainda mais sua imagem de poderoso, solicitou em 1726 a familiatura do Santo Ofício e o título de cavaleiro da Ordem de Cristo. Com este último não conseguiu ser agraciado, pois não obteve dispensa de seus impedimentos, no caso uma ascendência mecânica. ${ }^{51}$

Obviamente que nem sempre o estereótipo dos potentados se manifestava na figura de "fiéis vassalos" sempre prontos a servir ao rei, inclusive em momentos de perturbação da ordem pública, visando às mercês régias que referendariam sua "qualidade" social. Em diversas circunstâncias, procuravam se caracterizar pelo rigor de suas ações, pela agressividade de caráter e por constantes demonstraçóes de brio em público. ${ }^{52}$ E neste ponto podemos abordar um outro revés ocorrido com o armamento de escravos pelos potentados que antes aludimos, isto é, os abusos de autoridade praticados por tais homens. Esse era mais um elemento a contribuir para o clima de medo, instabilidade e violência, agora não tanto da parte da população negra, mas da parte de membros da elite. Se repetidas vezes fizeram uso de suas milícias particulares para socorrer ao rei e às autoridades metropolitanas, para adquirir mercês e prestígio, em algumas situaçôes podiam usar suas milícias para fazer valer suas vontades pessoais, abrindo procedência para se agir com desmando e violência, tornando esses indivíduos figuras temidas na regiáo. Entravam assim em conflito com autoridades, com outros membros da elite local, subjugavam ou "protegiam" indivíduos das camadas inferiores para demonstrar seu poder e sua autoridade locais.

Para exemplificar, destacamos uma denúncia feita contra o coronel Maximiliano de Oliveira Leite e seu cunhado o coronel Caetano Álvares Rodrigues. Maximiliano de Oliveira Leite era membro de uma das principais famílias de São Paulo, pois era neto do famoso bandeirante e governador das esmeraldas Fernão Dias Paes Leme e sobrinho do guarda-mor das Minas Garcia Rodrigues Paes Leme. Assim como seu avô e seu tio, Maximiliano também seguiu para a capitania mineira desbravando matas fechadas, trilhas indígenas pouco conhecidas, conquistando terras para a Coroa portuguesa, tudo em nome do enriquecimento imediato. Esteve entre os primeiros povoadores de Minas Gerais, fixando-se na freguesia de Sáo Sebastiáo onde residiu muitos anos e teve propriedades. ${ }^{53}$ Além da patente que possuía e da família a que pertencia, contribuíam para referendar seu prestígio e autoridade na localidade os importantes cargos que ocupou, no caso, o de guarda-mor e o de juiz ordinário na Câmara da Vila do Carmo no ano de $1726,{ }^{54}$ e os títulos de cavaleiro professo da Ordem de Cristo e cavaleiro fidalgo da Casa Real, ${ }^{55}$ que lhe davam reconhecimento em nível imperial.

\footnotetext{
${ }^{48}$ Arquivo Nacional da Torre do Tombo. Habilitação da Ordem de Cristo de Antonio Martins Leça. Letra A, Maço 51, doc 15. Data: 11 de maio de 1726.

${ }^{49}$ Memorial Histórico-Político da Câmara Municipal de Ouro Preto. Ouro Preto: Cor \& Cor Editorial, dez. 2004.

${ }^{50}$ STUMPF, Roberta. Nobrezas na América portuguesa, op. cit. p. 121.

${ }^{51}$ Ver, respectivamente: Arquivo Nacional da Torre do Tombo. Habilitação da Ordem de Cristo de Antonio Martins Leça. Letra A, Maço 51, doc 15. Data: 11 de maio de 1726. Arquivo Nacional da Torre do Tombo. Familiatura do Santo Ofício de Antonio Martins Leça. Completa, maço 68, doc. 1362. Data: maio de 1726.

${ }^{52}$ Ibid.

${ }^{53}$ FRANCO, Francisco de Assis Carvalho. Dicionário de bandeirantes e sertanistas do Brasil, op. cit. p. 211-212, $215-216$. Para análise detalhada do perfil deste potentado, ver: ALMEIDA, Carla Maria Carvalho de. Uma nobreza da terra com projeto imperial: Maximiliano de Oliveira Leite e seus aparentados. In: FRAGOSO, João Luís Ribeiro; ALMEIDA, Carla Maria Carvalho de; SAMPAIO, Antonio Carlos Jucá de (Org.). Conquistadores e negociantes, op. cit. p. 121-193.

${ }^{54}$ Acórdãos da Câmara Municipal de Mariana. Arquivo Público Mineiro. Seção Colonial — Cód. 02, 05 e 06.

${ }^{55}$ FRANCO, Francisco de Assis Carvalho. Dicionário de bandeirantes e sertanistas do Brasil, op. cit. p. 212.
} 
Já o coronel Caetano Álvares Rodrigues era português natural da Freguesia de São Julião da cidade de Lisboa. Ainda muito jovem iniciou a carreira militar embarcando para a Índia no posto de soldado. Com aproximadamente 23 anos, veio para o Brasil, onde chegou no ano de 1710, depois de ter servido por seis anos na Índia e de ter se destacado em várias batalhas de mar e terra. Neste ano já se encontrava na capitania mineira na qual realizou uma série de açóes na defesa dos interesses de sua majestade, o que o levou a receber muitas recompensas. Dentre essas destacam-se a patente de coronel das ordenanças de São Paulo em 1721, os títulos de cavaleiro da Ordem de Cristo em 1731 e de cavaleiro fidalgo da Casa Real em $1746 .{ }^{56}$

Com toda essa proeminente posiçáo social e poder de mando, Maximiliano e Caetano acabaram por violar ordens e abusar de sua autoridade em certas ocasióes, fazendo uso de violências em contendas pessoais. Em 1726, José de Soveral de Miranda, padre vigário da igreja da freguesia de São Sebastião, situada na região do Ribeirão do Carmo, enviou um requerimento para o Conselho Ultramarino solicitando justiça contra as violências praticadas por ambos. Segundo o padre:

Estando ele quieto e pacífico em sua casa no fim do mês de março deste ano de 1726 violentamente sem atenção alguma ao hábito sacerdotal vieram cento e tantos pretos armados de Maximiano e de seu cunhado Caetano Álvares Rodrigues e por sua ordem os ditos pretos arrombaram as portas e janelas do suplicante e entrando em sua casa lhe matara um preto por nome Jereasio a facadas. Lhe roubaram 300 oitavas de ouro e várias roupas de seu uso. Deram-lhe ainda uma estocada e um tiro que não resultou em morte. ${ }^{57}$

O desafeto entre os envolvidos começou porque o dito padre não quis confessar uma mulher "que o suplicado Maximiano lhe foi pedir confessasse, o que o suplicante repugnou por saber que andava o sobredito amancebado com ela". ${ }^{58}$ Percebe-se que, ao negar à concubina de Maximiliano o direito da confissão, o padre estava ofendendo também o potentado, pois em última instância o padre estava negando sua reputaçáo de homem poderoso diante da comunidade, na medida em que questionava e descumpria um de seus pedidos. Pode-se mesmo dizer que suas atitudes estáo inseridas dentro de uma dinâmica social, intimamente relacionada ao uso da violência, pois era exigido pela sua própria transformação em potentado local que soubesse distinguir os limites da atuação da população e manter longe os possíveis transtornos que pudessem atrapalhar sua autoafirmação e manutenção de sua integridade pessoal. ${ }^{59}$ Para tal fim, o coronel Maximiliano contou com a ajuda de seu cunhado Caetano Álvares Rodrigues, também coronel e homem poderoso das Minas, com quem sempre andava e fazia negócios "promiscuamente juntos". ${ }^{60}$

O caso relatado até foi parar em um tribunal, gerando a abertura de uma devassa. Mas Maximiliano era muito bem relacionado. O juiz ordinário responsável pelo processo, Belchior da Costa Soares, era "particular amigo do dito" e condenou à prisão apenas doze escravos "daquele grande número que cometeram as referidas insolências, e isso por amizade de ambos e para tapar a boca ao mundo". ${ }^{61}$

O exemplo denota que, ao lançarem mão de atitudes violentas, os potentados intentavam resguardar e delimitar o "território" de domínio de cada um e com isto garantir o prestígio, o poder local e a posse

\footnotetext{
${ }^{56}$ Arquivo Nacional da Torre do Tombo. Habilitação da Ordem de Cristo de Caetano Álvares Rodrigues. Letra C, Maço 12, doc. 6. Data: 24 de janeiro de 1730.

${ }^{57}$ Arquivo Histórico Ultramarino/MG/cx.: 8; doc.: 7. Grifos meus.

${ }^{58}$ Ibid.

59 SILVA, Célia Nonata da. A teia da vida: violência interpessoal nas Minas setecentistas. Dissertação (mestrado em história) - Universidade Federal de Minas Gerais, Belo Horizonte, 1998. cap. 1.

${ }^{60}$ ALMEIDA, Carla Maria Carvalho de. Uma nobreza da terra com projeto imperial, op. cit. p. 148.

${ }^{61}$ Arquivo Histórico Ultramarino/MG/cx.: 8; doc.: 7.
} 
do mando. ${ }^{62}$ E contribuía sobremaneira para tal fim o controle que esses indivíduos exerciam sobre milícias privadas de escravos armados que formavam grupos de capangas utilizados nestes desmandos.

Cabe ressaltar que, infelizmente, não conseguimos encontrar maiores informaçóes, tais como nome, idade, etnias, qualidade, estratégias, que nos permitissem montar um perfil acerca desses escravos armados controlados pelos potentados nas Minas. Normalmente, a menção da montagem dessas milícias era feita de forma genérica na documentação, sem maiores detalhes sobre esses homens armados que andavam com eles como guarda-costas pessoais ou em suas diligências para prestaçáo de serviços ao rei. Contudo, investigando fontes diversas referentes aos potentados e seus plantéis, conseguimos reunir alguns dados que talvez nos permitam fazer algumas inferências, mesmo que mínimas, acerca desses escravos. Mesmo não sendo este o tema do referido artigo, achamos interessante lançar algumas consideraçôes sobre o assunto para enriquecer a análise sobre o fenômeno do armamento de escravos. No que tange à montagem do plantel, percebemos que, entre os quatro potentados mencionados nesse texto, os escravos que possuíam nos períodos em que encontramos relatos descrevendo o uso de milícias privadas eram em sua maioria africanos, havendo ainda a presença de cativos designados por conotação militar.

O sargento-mor Paulo Rodrigues Durão, por exemplo, entre 1718-1720, era senhor de 76 escravos conforme revela uma lista para a cobrança do quinto no Inficcionado. Dentre estes temos 73 homens, sendo sete crioulos, cinco sem identificação de etnia e 61 africanos. ${ }^{63} \mathrm{Na}$ lista de Mariana datada de 1725 este potentado relatou ter um plantel de 65 escravos, composto por apenas cinco mulheres. Dentre os cativos homens, dois eram crioulos, doze sem identificação da etnia e 46 eram africanos. ${ }^{64}$ Em seu inventário datado de 1743, no qual foram arrolados 129 escravos, temos 99 homens. Desses, vinte eram crioulos, cinco sem identificação de etnia e 74 africanos. ${ }^{65}$

Para o coronel Maximiliano de Oliveira Leite encontramos duas listas para cobrança de quintos reais que podem nos dar uma pequena dimensão da quantidade de escravos que possuiu em determinado momento de sua vida. Considerando que as listas se referem a um período aproximado daquele em que localizamos relatos acerca do uso de milícias privadas por ele, essa correlação se torna ainda mais emblemática. As listas são referentes à freguesia de São Sebastião, uma datada de 1718 e outra de 1723. Na primeira dizia possuir 66 escravos. Dentre esses, todos eram homens, havendo dois crioulos, quatro sem identificação de etnia e sessenta africanos. ${ }^{66} \mathrm{Na}$ outra lista, declarava ter em sociedade com seu cunhado, o coronel Caetano Álvares Rodrigues, um plantel de 74 escravos. Estes se compunham de oito mulheres e 66 homens. Dentre eles, dois eram crioulos, quatorze sem identificação de etnia e os demais eram africanos. ${ }^{67}$

Já para o sargento-mor Antonio Martins Leça encontramos uma listagem para a cobrança dos quintos reais de Vila Rica feita para os anos de 1718-1723, na qual o referido potentado aparece com seu sócio Manoel Coelho Neto como senhor de 62 escravos. Entretanto, esta listagem está bem incompleta, o que nos impossibilitou de conhecer a etnia da grande maioria desses cativos. Só conseguimos identificar que, dentre os 58 homens, havia dezesseis africanos e um crioulo. ${ }^{68}$

\footnotetext{
${ }^{62}$ SILVA, Célia Nonata da. A teia da vida, op. cit.

${ }^{63}$ Lista de registro para cobrança dos quintos reais do Inficcionado, 1718-1720. Arquivo Público Mineiro, Coleção Casa dos Contos, códice 1035.

${ }^{64}$ Lista de registro para cobrança dos quintos reais de Mariana e seu Termo, 1725. Arquivo da Câmara de Mariana, códice 150 .

${ }^{65}$ Casa Setecentista de Mariana, 1o ofício - Inventário post-mortem de Paulo Rodrigues Durão. Códice 115, auto 2377 (1743).

${ }^{66}$ Lista de registro para cobrança dos quintos reais de São Sebastião, 1718. Arquivo Público Mineiro, Coleção Casa dos Contos, códice 1024.

${ }^{67}$ Lista de registro para cobrança dos quintos reais de São Sebastião, 1723. Arquivo da Câmara de Mariana, códice 166.

${ }^{68}$ Lista de registro para cobrança dos quintos reais de Vila Rica, 1718-1723. Arquivo Público Mineiro, Coleção Casa dos Contos, códice 1028 .
} 
Percebe-se assim que os potentados que estamos analisando no presente texto possuíam plantéis numerosos, com grande desequilíbrio sexual, alta taxa de masculinidade e de africanos, o que evidencia participação ativa no tráfico negreiro. Tais dados, por um lado, corroboram todo um cenário já apontado por uma historiografia que analisa o padrão de posse de escravos para a região em seus primórdios. Esses estudos defendem que foi ocorrendo um aumento da demanda de cativos na capitania conforme iam se desenvolvendo as atividades de mineração e, posteriormente, aquelas ligadas à agropecuária. Todavia, por outro lado, os dados denotam a importância desse tipo de configuraçáo dos plantéis para outras utilizaçôes dos cativos. Defendemos o pressuposto de que era constantemente necessário possuir um número substancial de homens capazes de pegarem em armas para montagem das milícias particulares de escravos por todos os motivos já expostos ao longo do artigo, ratificando o argumento de que nem sempre os escravos eram direcionados para trabalhos no eito. A relevância do fenômeno fica mais evidente quando nos deparamos nos plantéis analisados com escravos designados com nomenclaturas bélicas.

Entre os cativos de Paulo Rodrigues Durão, encontramos em uma das listas para cobrança dos quintos reais em que seu nome aparece um escravo capitão de nome Pedro ${ }^{69}$ e em seu inventário um escravo capitão de nome Joseh de etnia mina. ${ }^{70}$ No plantel de Maximiliano de Oliveira Leite e de seu sócio Caetano Álvares Rodrigues encontramos três escravos com designaçôes militares: um monjolo capitáo que estava listado sem o nome, um escravo de nome Joseh cabo e um escravo de nome Antonio marinheiro. ${ }^{71} \mathrm{O}$ mesmo se processava entre os escravos de Antonio Martins Leça e seu sócio Manoel Coelho Neto. Encontramos em sua listagem cativos que eram designados como Braz sargento, Lourenço capitão, um soldado mina e um escravo alferes. ${ }^{72}$ Como indicado anteriormente, estes potentados utilizaram seus escravos armados em variadas ocasiōes, com objetivos diferentes, tais como a contenção de revoltas, a captura e a punição de crimes cometidos por negros fugidos, a condução do quinto, bem como em contendas pessoais, abuso de poder e demonstração pública do mesmo. Desta forma, podemos supor que as habilidades bélicas de alguns cativos, que eram inclusive reconhecidas publicamente a ponto de serem designados com esse caráter militar, devem ter sido de grande ajuda. Tal fato indica que o senhor provavelmente escolhia aqueles escravos mais capazes para atuar como seu braço armado. Talvez optasse por aqueles que tivessem não só força, idade e capacidade para "pegarem em armas", mas também aqueles que tivessem habilidade para tanto, que podia ser proveniente de uma experiência até mesmo anterior à sua escravização na América, ou proveniente de sua atuação em várias diligências em que foram levados por tal senhor como braço armado. Em alguns casos, esses cativos ficavam mesmo conhecidos por tais habilidades, como evidenciam os documentos anteriores. Ou seja, do mesmo modo que encontramos nomes de escravos associados ao desempenho de alguns ofícios, tais como ferreiro, cozinheiro, sapateiro etc. — o que inclusive ocorria entre alguns cativos dos potentados assinalados —, encontramos também alguns nomes de escravos associados ao desempenho de funçôes bélicas.

Conclui-se, portanto, que em um quadro inicial política e socialmente conturbado, de organização incipiente em uma das comarcas mineiras, as milícias particulares de escravos armados se transformaram em um recurso largamente explorado por se constituir em expressão de poder, mando, domínio, negociação, convívio e auxílio na governabilidade local. Mas que não deixou de fomentar tensóes, conflitos, receios e dificuldades para a Coroa portuguesa, as autoridades metropolitanas e os demais habitantes coloniais.

\footnotetext{
${ }^{69}$ Lista de registro para cobrança dos quintos reais do Inficcionado, 1718-1720. Arquivo Público Mineiro, Coleção Casa dos Contos, códice 1035.

${ }^{70}$ Casa Setecentista de Mariana, 1o ofício - Inventário post-mortem de Paulo Rodrigues Durão. Códice 115, auto 2377 (1743).

${ }^{71}$ Lista de registro para cobrança dos quintos reais de São Sebastião, 1723. Arquivo da Câmara de Mariana, códice 166.

${ }^{72}$ Lista de registro para cobrança dos quintos reais de Vila Rica, 1718-1723. Arquivo Público Mineiro, Coleção Casa dos Contos, códice 1028 .
} 